\title{
Biology High School Science Curricula for the 21st Century
}

\author{
Mahmood Khalil1, Reuven Lazarowitz ${ }^{2}$, Rachel Hertz-Lazarowitz ${ }^{3}$ \\ ${ }^{1}$ The College of Sakhnin, Academic College for Teacher Education, Sakhnin, Israel \\ ${ }^{2}$ Department of Education in Technology and Science, I.I.T-Technion, Haifa, Israel \\ ${ }^{3}$ Faculty of Education, University of Haifa, Haifa, Israel \\ Email: mahkh@macam.ac.il, rlazar@tx.technion.ac.il, rachelhl@edu.haifa.ac.il
}

Received 7 July 2014; revised 30 July 2014; accepted 18 August 2014

Copyright (C) 2014 by authors and Scientific Research Publishing Inc.

This work is licensed under the Creative Commons Attribution International License (CC BY).

http://creativecommons.org/licenses/by/4.0/

c) (i) Open Access

\begin{abstract}
High school science curricula of the 21st century have to include science-technology content and pedagogical content knowledge in a continuous interaction in order to be relevant to students' needs. Learning units, including science, technology and related societal issues written on the Science, Technology and Society (STS), approach have to use teaching/learning strategies, and learning settings, such as cooperative learning in small groups, individual learning and computer episodes, so students will acquire science-technology literacy connected to societal issues. This approach may provide integration and participation in the advance society, so students will be able to look and find a job based on their learning. Dreyfus (1995) emphasized the importance of moral and ethics education. Science knowledge is not only for academic achievement and mastery of cognitive and meta-cognitive skills, but to educate students on the affective domain being active in the community life based on moral and ethical values, and positive attitudes toward societal issues, like social justice. Preservation of the environment and peace, as other values are addressed in the learning units presented.
\end{abstract}

\section{Keywords}

Curricula, Education, Inquiry, Content, Pedagogical Knowledge, and Societal Issues, Ethics and Moral Values

\section{Introduction}

High school science curricula have to include side by side science-technology content knowledge as well as pedagogical content knowledge in a continuous interaction in order to answer issues of relevancy of both of them 
to students’ needs.

Two main roles of science education for high schools students will be addressed, so science curricula will be adequate for the 21st century.

1. With the role of Science Technology Society (STS) learning units, which have to use specific teaching/learning strategies, and specific learning settings, students will acquire science-technology literacy connected to societal issues, which can facilitate their integration and participation in our advance society and will be able to find a job based on their learning;

2. The role of moral education, values and attitudes via acquiring knowledge in science content knowledge is as Dreyfus (1995) emphasized that “biological knowledge is a prerequisite for the development of students' values and attitudes”.

Science knowledge role is not only for academic achievement and mastery of cognitive and meta-cognitive skills, but to educate students on the affective domain being active in the community life based on moral values and positive attitudes toward societal issues, like social justice, preservation of the environment and peace, the last two being addressed due to the fact of having a mutual impact connection in one of the STS learning units presented in continuation.

Section 1 will include three parts:

1.1. The model of the six mirrors of the classroom as developed by Hertz-Lazarowitz (1992), which can support teaching-learning in three complex cooperative learning methods;

1.2. Cooperative learning methods. The Group Investigations (Sharan \& Hertz-Lazarowitz, 1980, 1986), the Jigsaw method (Aronson et al., 1978) and Peer Tutoring in Small Investigative Groups (PTSIG, Lazarowitz \& Karsenty (1990));

1.3. Three learning units developed on the STS approach and taught using the six mirrors of the classroom are presented in order to show the integration of methods of teaching-learning and the STS approach.

\subsection{The Six Mirrors of the Classroom in the Traditional Instruction}

Figure 1 presents the six mirrors in four wings and shows the learning activities that occur in traditional (expository) classrooms. Those learning activities may be depicted as follows (See Figure 1). Mirror 1. The traditional classroom usually means direct, whole-classroom instruction (also called frontal or expository teaching). One can perceive the physical organization of the traditional classroom as fixed with little or no movement of the students within it.

Mirror 2. The teacher presents the learning tasks to the whole class, and then each student tackles it on his/her own.

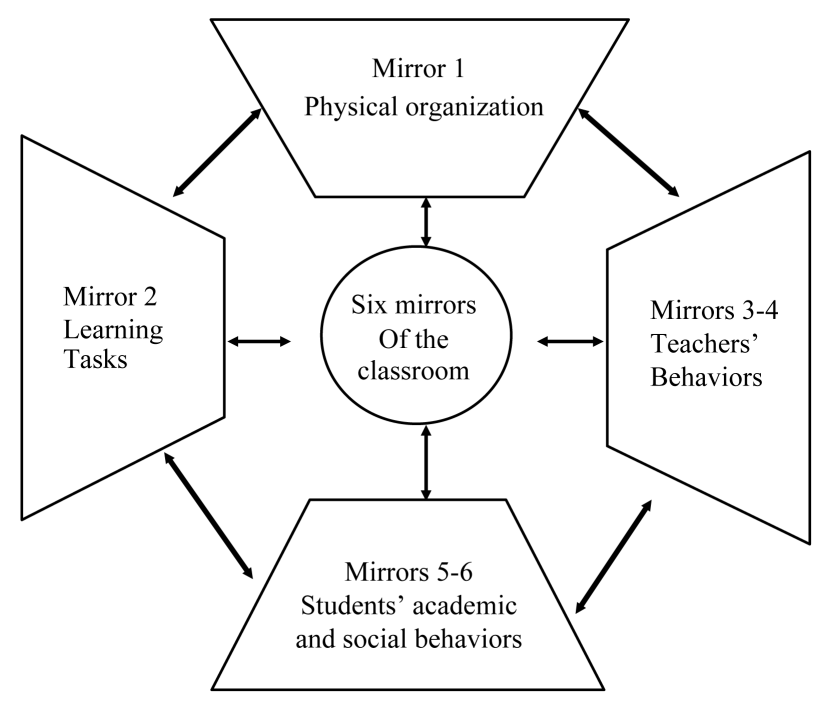

Figure 1. Six Mirrors of the Classroom in the traditional expository teaching (Hertz-Lazarowitz, 1992). 
Mirrors 3 and 4. The teacher communicates with the class as a whole with a high frequency of lecturing, disciplining, and commenting on negative events in the classroom.

Mirrors 5 and 6. Students' behaviors are mostly solitary on-task and off-task activities. Interactive behaviors, which include on-task and off-task and helping activities, occur about 25 percent of the time. Teachers do not initiate interactions among students-in fact, the interactions consist mainly of brief, clandestine types of activities.

Developmental observations showed that from first to twelfth grade, students maintained a stable interactive "on-task behavior" (about 15\%), but increased their "off-task" interactive behaviors (Lazarowitz, Hertz-Lazarowitz, Baird and Bowlden, 1988). Teachers considered the increase in social "off-task" interactions to be a negative outcome, indicating increasing discipline problems and disturbances of the teacher's classroom (see Figure 1).

The model was designed to examine classroom processes and includes six aspects (mirrors) of the classroom 1) organization; 2) learning tasks; 3) instructional behaviors of the teacher; 4) communicative behaviors of the teacher; 5) academic performance of the students; and 6) social behaviors of the student. Each mirror is described in terms of five levels of complexity from simple to complex (Hertz-Lazarowitz, 1992) as presented in Figure 2.

The model can serve as a conceptual framework to guide classroom observation in behavioral categories such as "on-task" and "off-task" behaviors, level of cooperation in the interaction of the students, and helping and social events that take place during the learning. It can be used to train teachers to design their classroom environment and move from traditional whole-classroom instruction to more active and then cooperative learning. The model and its measures assist teachers in testing the effects of cooperative learning on students' academic and social outcomes. The conceptual dynamics among the six mirrors permit the formulation of predictions and the analysis of a range of variables-for example, quality of on-task cooperation as expressed by content, frequency of in-group communication, level of reasoning, and predicted academic and social outcomes.

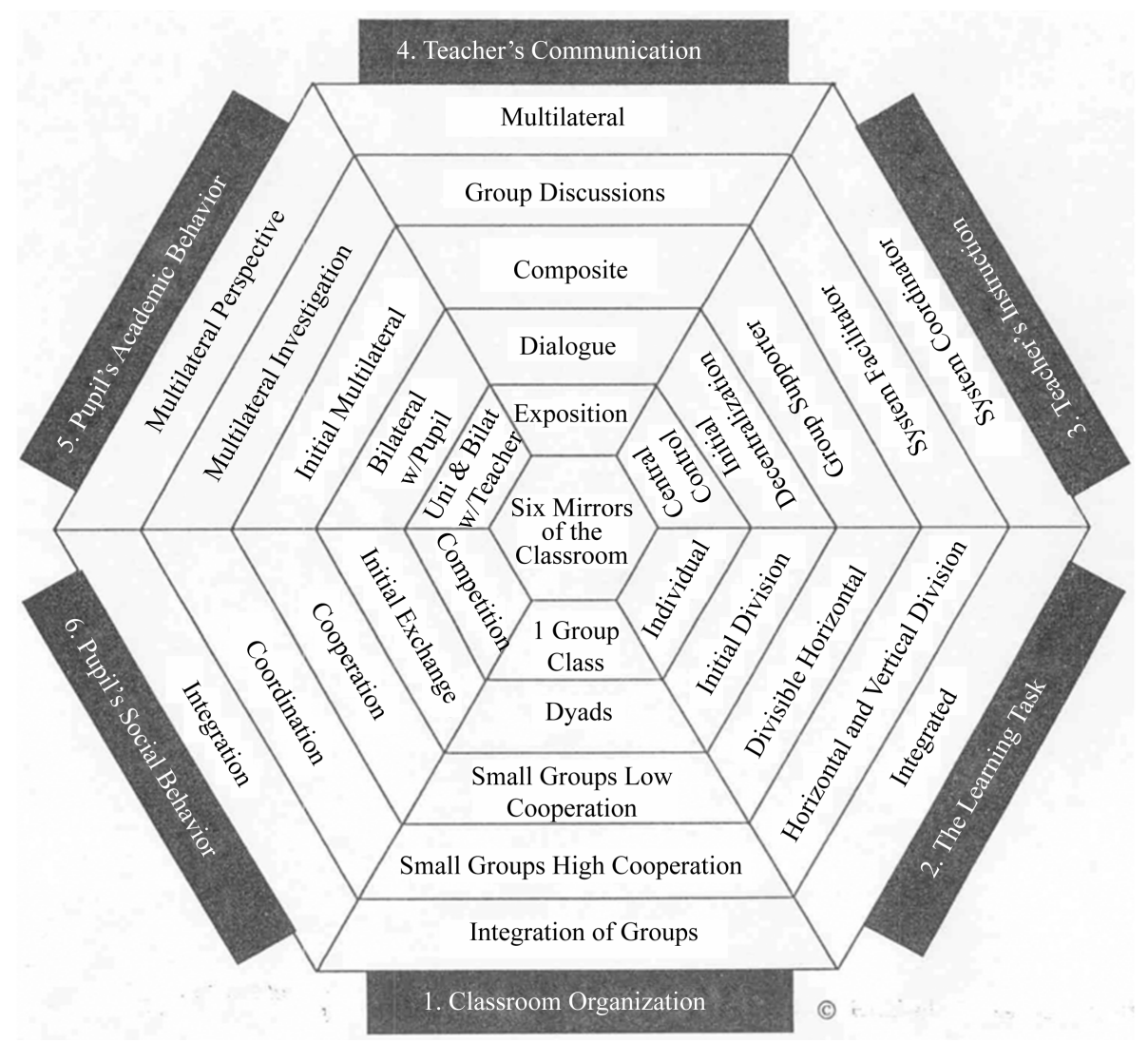

Figure 2. The Six-Mirrors of the Classroom (SMC) model (Hertz-Lazarowitz, 1992). 
The model can be used to train teachers to design their classroom environment, and move from traditional whole classroom instruction to more active and then cooperative learning.

Classroom structure and dynamics can be obtained, using video tapes and observers' coding. Studies' findings indicated that there were differences between traditional classrooms, where frontal teaching was dominant, as compared to active and cooperative classrooms, with considerable student interaction.

Co-operative learning in instructional and learning processes has some advantages: it provides in-depth learning, leads to diverse learning methods and social interaction. This integrative method increases interest in learning, leading to comprehension of content and successful learning. The basic premise in co-operative learning is that it motivates active learning by students, encourages group processing of information, and strengthens meta-cognitive activities (Lazarowitz \& Hertz Lazarowitz, 1998).

In contrast to traditional classrooms, teachers designed their Cooperative Learning classrooms so that the physical setting (Mirror1) included 4 - 5 subsystems (groups), multiple resources for learning, and considerable movement and contact among the groups. Learning tasks (Mirror 2 were divided horizontally, as in a Jigsaw structure, or vertically and integrated, as in the Group Investigation method. In the jigsaw method, students are assigned to groups of about 4 - 6 members, with all groups working on the same topic. In each group, each member studies a different section of the topic, and then members from all groups who studied the same section meet in "expert groups" to discuss their section. Student then return to their groups and teach their group members about their section. In Group Investigation, students in the class form groups of 2 - 6 members, each group chooses a subtopic from the general topic assigned to the class, and produces a group report. Subsequently, each group shares its findings with the entire class in the form of presentations and class discussions. These Cooperative Learning tasks, which involved peer learning and peer teaching, were designed to increase interdependence and personal as well as collective responsibility.

The pattern of teacher's communication and instructional behaviors (Mirrors 3 and 4) included communication with the whole class for a short period of time, then with each of the groups as well as with individuals who needed help. The teacher observed a given group at a time and helped advance the group's discussion to a higher level. Most of the time teachers were helping, explaining, and giving feedback to students. Little disciplining took place and only a few negative comments were heard in the class.

In this context, students engaged quite frequently in interactive, cooperative and helping behaviors. It was observed that within lively and stimulating group discussions, peer learning was at a high cognitive level. These descriptions of class activities and dynamics exemplify how the "anatomy of cooperation" model of the six mirrors enabled the observation and investigation of academic outcome.

\subsection{Cooperative Leaning Methods in the Science Secondary Schools}

\subsubsection{The Jigsaw Method (Aronson et al. 1978)}

In the jigsaw method, the class is divided into small groups of heterogeneous five students who can treat each other as resources. The learning goals and materials are structured by the teacher and are divided into independent sub-units which can be learned separately so that one sub-unit does not depend on the mastery of others.

The jigsaw is composed from two cooperative structures; the jigsaw (5 students A to E) and the experts group (5 students with the same part $5 a, 5 b, 5 c$, etc.). In the expert group student master their part and prepare for peer-tutoring, then they return to jigsaw group to tutor their teammates and prepare for a test.

Group Investigation (GI) (Sharan and Hertz-Lazarowitz 1980, 1986)

Group investigation is rooted in Dewey's (1927) philosophy of education. GI integrates four basic features: investigation, interaction, interpretation and intrinsic motivation. These features are combined in the six stages of the GI model:

1) Class determines subtopics and organizes into research groups; 2) Groups plan their investigation; 3) Groups carry out their investigation; 4) Groups plan their presentations; 5) Groups make their presentation; 6) Teacher and students evaluate their projects. In GI the investigation process is presented in each stage; groups select topics for investigation by their interest and curiosity. Thus in the GI classroom groups work on different, but related topics of investigation. They use a variety of resources to generate questions, gather information in the investigation and become active in constructing their knowledge. The teacher is a facilitator, a mentor and a collaborator in the student's inquiry process. 


\subsubsection{Peer Tutoring in Small Investigative Groups (PTSIG)}

The method was developed by Lazarowitz and Karsenty (1990) as a combination of the Jigsaw method and Group Investigation (GI). The PTSIG was experimented in secondary school. The method include the following structures: The Jigsaw structure for peer-tutoring, and the GI structure for the expert counter group. The teacher as a curricula developer, designs the biology related learning tasks for each sub-unit, in an inquiry-investigative sequence of activities. Therefore, students work, especially in their expert group, on complex and rich learning tasks. In their expert-group students are reading, making observations on the objects studied and generate questions for laboratory investigative experiments. The tasks include open questions and biological problems which could be solved only by using microscopes, preparing slides or performing experiments with other group members. After they finish their learning tasks in the expert group, they return to their Jigsaw group for peer tutoring. Usually, the different sub-topics which were investigated are presented and discussed within the original Jigsaw group in order to acquire a general understanding and knowledge of the topics.

The evaluation is based on students' academic products in their expert groups, and their grades in a test on all the units. The students prepare for the final test with further reading. The teacher occasionally leads the discussion with the whole class to organize and conceptualize significant biological concepts. Topics such as the cells, animal physiology, photosynthesis in higher plants, and evolution are topics that can be naturally divided into five independent sub-units and can be learned in a jigsaw investigative method. Teachers-Researchers in Israel, who have implemented PTSGI, develop elaborate curricula to be used in high-school biology classrooms.

In both methods the investigative method the students and the teachers contain and practice complexity in each of the mirrors as presented in the 5th level of the model (Hertz-Lazarowitz, 1992: p. 73-81).

The positive academic and social outcomes of Cooperative Learning are presented in many writings: Abrami, P. C., Poulsen, C., \& Chambers, B. (2004), (Gillies \& Ashman, 2003; Hertz-Lazarowitz, 1992, 2005, 2008; Lazarowitz \& Hertz-Lazarowitz, 1998; Lazarowitz, 2006; Slavin, Hurley, \& Chamberlain, 2003).

\subsection{Modules Developed in the STS Approach as They Were Taught at the Secondary School Level}

\subsubsection{Ionizing Radiation: Uses and Biological Effects}

The learning unit Ionizing Radiation: Chemistry and Biological Effects (Nachshon, 2000) was written in a thematic and STS approach and included related subjects: a) the physics-chemistry of ionizing radiation - the particle radiation of Alpha and Betarays, electromagnetic radiation, gamma and X-ray radioactive phenomena and background radiation; b) biological aspects - the effects of radiation on different levels of biological organization: the molecules (DNA molecules), organelles, cell, tissues, and organisms; c) the technological aspects-radioisotopes as energy and radiation sources, the food industry, science research, the range of medical uses of X-ray photography and computerized tomography (CT); and d) societal aspects and issues uses of ionizing radiation for human needs, the use of radioisotopes for diagnosis and treatment in nuclear medicine, the use of nuclear power for electricity (advantages and disadvantages), and the use of this energy as possible weapons of mass destruction, the process of mutation, and the relationship between cancer and damage repair mechanisms and ionizing radiation's immediate effects and long-term effects, which may affect cell life cycles. The implementation and evaluation in grades 10 and 11 revealed that students' fluency and elaboration on ideas were higher while they learned in cooperative groups rather than as individuals. One-third of the students asked higher order questions, and the questions of the other students were mainly on the knowledge and comprehension levels. Half of the students were interested in the physics of ionizing radiation and activities aimed at developing creative thinking. Students preferred to learn the subjects in the thematic mode, in group activities, and most of them mentioned the importance of the diversity in instructional strategies that were used. The academic achievement of students in control groups, who learned chemistry and physics subjects in a disciplinary approach, was significantly lower, whereas the achievement of those who studied the subjects in the STS mode was higher. All students mentioned that learning about nuclear and ionizing radiation and their uses for human needs in a thematic approach and STS mode helped them to overcome their fears, which have based on a lack of knowledge and prejudice (Nachshon, 2000).

\subsubsection{Microorganisms}

This learning unit was developed in Arabic and Hebrew for 9th grade Israeli and Arab students in the STS ap- 
proach, by Khalil Mahmood (2002), investigated by Khalil, Hertz-Lazarowitz and Lazarowitz, 2009). The learning unit was structured around two main biological principles: the unity of the life in the world and the relationship between structure and function. The problems raised in the unit were concerned with health issues, environment, microorganisms and drainage canalization between neighborhood villages. This unit enabled to investigate students' achievement on the cognitive and on the affective domains, attitudes toward the preservation of the environment and understanding and peace between people who live close to each other (Khalil, M. 2007). The following topics were included in the learning unit: microorganisms and their structure, the physiological processes, microorganisms' role in the food web, carbon and nitrogen cycles, food industry, environment and the level of health society. The unit helped students to master practical skills in the laboratory work, and to develop scientific thinking and problem solving skills. The learning tasks included individual and small cooperative group, utilizing a variety of teaching and learning methods in the classroom and the laboratory work within the model of the six mirrors of the classroom. Students read scientific essays, watched videos, played group games, went on group trips in the nature, visited food industries and searched for information from different sources, internet and libraries. The learning unit was introduced to the students in such a manner as to raise students' motivation by being practical, connected with daily life and dealing with societal issues. In this manner the relationship between science, technology, environment and society was emphasized.

It was assumed, that students would develop positive attitudes and be able to objectively judge the problems involved with the preservation of the environment, while understanding the important role of the microorganisms in the life web. The outcomes in the cognitive and affective domains were obtained by analyzing students' portfolios written while studying in the classroom, in the laboratory and during the execution of their homework. The results show that students gained in their academic achievement, developed positive attitudes toward the environment, and understood the role that people have concerning the preservation of nature and its relation to peace, (Khalil, 2000; 2002).

\subsubsection{Evolution}

In the study conducted by Ron and Lazarowitz, (1995) with 12th grade students, the topic of evolution was taught in an instructional mode of cooperative learning groups within the model of the six mirrors of the classroom. The topics were; Lamarck's, Darwin's and neutral theories, punctuated equilibrium, genetics diversity, natural selection, specialization and phylogenesis. The results showed that students' academic achievements were higher compared with the control group. The explanation was based on the fact that cooperative learning in an active mode of SMC facilitates students' verbal interaction and construction of the knowledge based on group interaction and cooperation (Ron and Lazaroowitz, 1997).

Teaching and learning in the classrooms and laboratory work offered many opportunities for the evaluation and grading procedures, beside the use of the classical test following the instruction of a unit (Lazarowitz, 2000; Lazarowitz and Tamir, 1994).

In implementing these methods, a complex and rich teaching and learning processes took place in the classroom. The teacher had to become an engineer of the learning tasks, and a designer of the physical setting of learning, as he orchestrated instructional and communicative behaviors to produce quality learning that will maximize the social-academic performance of the students.

\subsubsection{Laboratory Work}

Can ninth graders students identified as being in the concrete operational stage learn the concept of $\mathrm{pH}$, which requires formal operational ability?

In their study, Witenoff and Lazarowitz (1993), found that when the laboratory worksheets from which students perform the experiments, are restructured according to Farmer and Farrell, (1980: p. 64) suggestions, and taught in cooperative groups, they achieved significantly higher grades than the control group. It can be seen that when the cognitive operational stages of students are identified and the learning material was restructured in order to fit students' cognitive stage and learning style, learners can succeed. The biology teaching and learning in the classrooms and laboratory work offers many opportunities for the evaluation and grading procedures, beside the use of the classical test following the instruction of a unit (Lazarowitz, 2000; Lazarowitz and Tamir, 1994).

Implementing these methods, the six mirrors of the classroom integrated in cooperative small group instruction, a complex and rich teaching and learning processes are taking place in the classroom. The teacher has to become an engineer of the learning tasks, and a designer of the physical setting of learning, as the teacher has to 
orchestrate her/his instructional and communicative behaviors to produce quality learning that will maximize the social-academic performance of the students.

Teaching and learning STS modules in a cooperative approach within the model of the six mirrors of the classroom, requires classroom learning environments different from the traditional one.

\subsubsection{The Learning Material and the Teacher}

How to prepare the learning material? The regular textbook cannot facilitate cooperative learning within the six mirrors of the classroom mode and active learning. They can serve only as sources of information. Is the role of the teacher to prepare subunits by choosing those subjects, which can be divided in 5 subunits, and which can be learned independently but when they are presented by each student, they display an entirety.

1. Teachers have to develop the subunits so that some of them will require higher cognitive demands and some demanding less and to distribute them accordingly. In these methods both students with higher and lower cognitive abilities can contribute their parts in the learning process. One of the dilemmas that can rise is the fact that students who finish learning and preparing themselves earlier may feel unsure if other students can teach them or what to do with extra free time or if the teacher knows them as being better prepared. Here is the role of the teacher to identify them and to ask them to help the other students in their tasks given them the role of teachers' assistants.

2. To prepare additional learning material available in the classroom or laboratory, so students can move and look at them.

3. In contrast to the Learning together method in which students have not specific roles, in the 3 methods depicted earlier, each student is responsible for one part and depends on other for their parts. That way, students acquire skills of active learning, self and mutual responsibility and have to master cooperative skills needed so much today.

Those cooperative skills should be performed and mastered at the beginning and no one can hope that they will be acquired during the learning process itself. As it has been said students will be so much busy with the new method and with the new subject, so we cannot expect that simultaneously they will display cooperative skills.

Specific drills are suggested in their book by Aronson, et al. (1978).

\subsubsection{Student-Teacher Interaction and Active Learning}

As we see the teacher role is changing from provider the knowledge as is in the expository teaching, to be the provider of an environment in which students are responsible for the learning material, which was prepared in advance. The teacher can ask students to plane steps in order to accomplish the learning task in an active process. The class (course) moves from a teacher centered to student centered. Now the real role of the teacher can be displayed. The teacher can move now from one group to another, to stimulate, to ask, to answer and to devote more time to those who need him/her more and to praise students for their learning. We call this teacher the "floating teacher".

\subsubsection{Students' Heterogeneity}

Students differ in their cognitive stages, abilities, learning styles, preferences, choices, interests and needs. In the frontal expository teaching class, students who are peripherals, cannot express their learning difficulties when the teacher will ask the entire class “did you understand?” or “do you have questions?” Is very interesting if in this situation and in the front of all the class, can be find one student that will announce, "I did not understand".

In the cooperative group student can ask a student "tell me again" and the words used are more meaningful then those used by the teacher. The teacher can be also more helpful helping a student discretely then in front of the entire class.

\subsubsection{Evaluation and Outcomes}

In the expository teaching classrooms the teacher teach (lecturing) and provide all the knowledge-information, while the students' activities resume on listening, taking notes and trying to memorize the facts. Could these activities be called "learning"? Teachers' lecture resume on asking the traditional questions "Did you understand?" or "Do you have questions?" This type of teaching-learning is based on "one way interaction", which cannot provide equal dialog between teacher-students or among students-students. We were used to call it "teachers 
centered mode".

What happen in the three cooperative learning depicted above?

a) Teachers roles were depicted above.

b) Students' activities varied according to the learning tasks.

c) They read the tasks while each one received a task at a different cognitive level in order to meet the heterogeneous nature of the group members.

d) every student reads, prepare his/her part for teaching it to the other members of the group, each one in his/her mode by mentioning the important points or other methods, they check themselves for mastery of the knowledge and if they are ready to teach and prepare questions to ask their counterparts if they master the learning material and will be ready to take the test administered by the teacher at the end of the learning unit. As one can see, each student repeats the learning material by different ways (to learn is one think but to prepare it for teaching is a different activity). It was found that all these activities enable students to repeat in different ways, fact which assure a better memorization without being boredom. Students can interact, ask, and answer among themselves and with the teacher, who can suggest, stimulate and adding information so the cognitive levels of learning process rise. Beside these cognitive activities, two more kinds of skills are enhanced. 1) The affective objectives, responsibility behavior, helping, listening, sharing and more; 2) If the laboratory work is involved, then the psychomotor skills are enhanced too. Bloom taxonomy (1956) was widely cited for almost a half of the century but only the cooperative learning enabled teachers and students to acquire the learning skills on the three domains advocated by him, the cognitive, affective and the psychomotor areas in an equal educative mode using them as learning and teaching tools.

\section{Moral, Ethics, and Human Values in Biology Education}

The need to relate to moral ethics and values, while teaching students in Biology was mentioned by (Bybee, Harms, Ward, \& Yager, 1980). In 1976 Gottlieb noted that public school teachers do not relate to these issues while teaching science. As a result one may assume that most of the students on the high school level and college are not exposed to moral, ethical and human value discussions while learning science and technology. Some of these students are the people who later in their lives will become science teachers, medical doctors, scientists and politicians or common citizens.

Should science teachers address ethics, moral, and human values as part of their educational role, in addition to teaching subjects like genetics, genetic engineering, the human genome, molecular biology, topics in ecology and population issues, subjects, which have today an important role in the society life. Can citizens with no scientific knowledge and its connection to moral, ethics and human values react to those issues raised in a democratic society, while they did not practiced in their past any kind of discussion based on evidences and not on prejudices? This question was raised by Dreyfus (1995) who wrote that "teachers must try to present facts in their wider perspective of some biological principles, such as those of studies on behavior and ecology. This will enable students to develop the eclectic values of an educated member of society”.

\subsection{High School Biology and Societal Issues}

Analyzing high school biology textbooks Rosenthal (1984), found that between 1963 and 1983 attention to societal issues decreased in. Those books had minimized the controversial aspects and avoided questions of ethics and values, lacked a global perspective and neglected the interdisciplinary nature of problems. Her conclusion was that while some bio-ethic aspects were mentioned, almost none of the societal problems such as environment, population and human behavior were referred to in the books of the 80's, contrary to the books of 1973 . The general picture showed a declining emphasis of societal issues on the school textbooks.

Conner (2000a) noted the importance of including bio-ethical issues in order to provide opportunities for students to be prepared to respond to issues in adult life by giving them experience in discussing personal, social and ethical dilemmas related to science and technology.

The need to incorporate societal issues that are associated with science and technology subjects into science curricula was advocated by Layton (1993), while relating to the instructional mode needed in order to relate to societal issues Gilbert and Hoepper, (1996) mentioned that social interaction is essential for creating situation, which can challenge, refine and affirm our values. Teachers must create open and supportive classroom discussions in which students bring a wide range of viewpoints and evaluate issues from their personal point of view, 


\section{(Dawson, 1998).}

Students should get learning opportunities which require the use of higher thinking skills, such as analysis, synthesis, critical reflection and evaluation of their ideas about social and ethical issues. These should be provided in the context of learning topics, which are relevant to students (Lipman, 1991: p. 50; Anderson 2003; Bryant 2002; Bryant and Baggott la Velle, 2003).

At the college level, Sadler and Zeidler (2005) explored how students negotiate and resolve genetic engineering dilemmas. They reported that students demonstrated "evidence of rationalistic, emotive and intuitive forms of informal reasoning" and most of them "appreciated some of the moral implications of their decisions". Sadler and Zeidler (2005) concluded that science classrooms are environments where in addition to reason, intuition and emotion are valued.

The literature cited above emphasized the need of using learning material, which include science and technology knowledge related to societal issues, and teaching/learning strategies such as cooperative group learning, which stimulate active learning, students-teachers interaction and discussions trying to use relevant knowledge regarding moral ethical and human values.

Previously, active learning was depicted in the six mirrors of the classroom model as well as cooperative group learning settings, followed by the STS learning units in, which two issues in the affective domain, the preservation of the environment and peace were discussed.

At this point we will present a study carried by Lazarowitz and Ilit Bloch (2006) "Awareness of Societal Issues among High School Biology, and Teachers Teaching Genetics”, in which the issue of moral, ethics and human values served as the main goals of investigation while teaching genetics, genetic engineering, molecular genetics, human heredity and evolution to high school students.

The purpose of this study was to investigate how aware of societal issues (values, moral, ethic, and legal issues) are high school biology teachers while teaching the above subjects mentioned above.

Meanwhile referring to science and technology teachers, Conner (2000b) raised the problem that since they are often only specialists in their subject matter, they may encounter pedagogical difficulties which require discourse on STS issues. The need for guidance in these matters is probably pivotal in order for them to be able to act as facilitators on these issues.

In their study, Lazarowitz and Bloch (2006) asked the following questions:

1. Are high school biology teachers aware of the social dilemmas while teaching subjects in genetics?

2. What are the subjects in genetics that, in the teacher's opinion, should be taught in high school?

3. Do these subjects include societal issues (values, moral and ethics)?

4. What are the reasons given by the teachers in favor or against including societal issues in their classes of genetics, molecular genetics, genetic engineering, and evolution?

5. Do teachers differ in their opinions as to their awareness of these issues due to their years of teaching experience, gender or religious faith?

The sample consisted of 30 biology teachers (female, $N=25,83 \%$ male, $N=5,17 \%$ ) in urban and rural high schools. Seven teachers, 23\%, had teaching experience of 5 years; 9 teachers, 30\%, had teaching experience of 6 to 10 years, and 14 teachers, 47\%, had teaching experience of 11 years and more. Regarding religious faith, 6 teachers (20\%) were identified as being orthodox; 5 teachers (17\%), as being traditional and 19 teachers, (63\%), as being secular.

The small sample is due to the fact that very few biology teachers choose to teach the 5 points level of either genetics or evolution (the highest level required for the matriculation exams of students at the 11th and 12th grades).Teachers of these subjects were approached either by mail or personally by the researchers and asked to participate in the study. Therefore the sample can be considered of reasonable size, representing the teachers' population teaching these subjects.

Personal information and professional opinions of the teachers were gathered from questionnaires and individual interviews carried out by the researcher and a Teachers' Questionnaire in which teachers were asked to provide personal information; gender, years of teaching experience and religious faith (orthodox, traditional or secular), and two seven open questions on the topics taught (molecular genetics, genetic engineering, human heredity, evolution) and teachers' opinions on the related topics as follows:

1. List the main topics in genetics, molecular genetics, genetic engineering and human heredity and how this content is related to the subject of evolution that you teach in your classes. 
2. What subjects in the above mentioned topics do you emphasize the most?

3. If you were asked to change parts of the curriculum regarding these topics, which subjects would you recommend to extend?

4. If you were asked to include the topic of Cystic Fibrosis (CF) in the curriculum, into which subjects would you integrate in it?

4a. Are there other issues concerning CF that you would relate to in your teaching?

5. If you were asked to integrate the topic of the Fragile X Chromosome Syndrome (FXCS), in the curriculum, what related subjects would you like to include?

5a. What issues on FXCS would you relate to in your teaching?

6. If it was in your power to change or add content in your textbook, what topics on human heredity and genetic engineering would you suggest?

7. What subjects would you suggest to integrate into the teaching on the topic of embryo's cloning?

\subsection{Individual Interviews}

Due to the small size of the sample, all the teachers $(\mathrm{N}=30)$ were interviewed and tape recorded by the researcher, with their permissions.

The Guided-Focused Interview was found to be adequate for this study (Sabar-Ben Jeshua, 1997). This type of interview is based on a manual, with detailed questions related to the study goals, and the respondent had the freedom of reply and react and the interviewer could react to the new points raised by the interviewed.

The advantages of this type of interview are a) individual reactions; b) effective is use of time; c) consideration of important points; d) focus, but the person interviewed is free to react and present ideas. Thus, the respondents' answers can be compared, clustered and analyzed.

The analysis yielded four main categories: a) Genetics Population; b) Molecular Genetics; c) Genetic Engineering; d) Societal Issues: values, moral and ethical implications. Additional categories were: Practical Issues, General Scientific Subjects and Pedagogical Issues. Teachers' answers were analyzed according to categories for each research question and to years of teaching experience, gender and religious faith (secular, traditional and orthodox).

The results have shown that out of 125 responses most of them belong to scientific categories. The number in parenthesis, which follows a category, indicates how many times it was mentioned. Basic genetics (76 items, $60 \%$ ); molecular genetics (24 items, 19\%); and genetic engineering (18 items, 14\%). Only 7 items (6\%) were found to be related to the societal implications category. While one compares the number of topics between the scientific subjects and the societal issues then a big gap of 118 items vs. 7 only, becomes obviously. Topics primarily emphasized were genetic diseases, Mendel principles, sex determination and blood types in Basic Genetics and Population categories. In the second category, genetic engineering and application of medicine and agriculture were emphasized. Only three teachers mentioned the 7 items in the societal implication category.

Teachers' responses to question 2 were gathered in the same four categories and the results have shown about the same distribution between the scientific categories and the societal implications regarding the question related to what teachers will mostly emphasize in their teaching. Although the responses are different in content, the same ratio appears between the scientific items and the societal ones. On this question, 25 teachers answered, but only four of them mentioned societal issues. Teachers' responses to question 3 were clustered in three categories: Only 13 teachers answered this question and 3 categories were identified as being based on 18 responses. Ten topics were suggested for the scientific and practical categories and 6 for the societal one. While teachers were willing to add ethical subjects, they preferred specialists to deal with genetic counselling and subjects like limits acceptable or prohibited regarding the genetic engineering issue. They indicated that they themselves were ready to deal with ethical problems. Again, while on scientific and practical subjects they were ready to add topics to their instruction, there was a tendency to refer the societal issues to others.

Teachers' responses to question 4 were clustered in two categories:

Teachers were required to add to their curriculum the topic of Cystic Fibrosis disease (CFD), and what subjects they will integrate. They mentioned 43 items on the scientific field and only 5 related to the societal area. This topic is not in their curriculum and is not found in the textbook they used. Though mentioning scientific topics, teachers did not necessarily manifested knowledge about the disease. Moreover, the majority of the teachers did not find it necessary, or simply did not consider it their role to relate to the societal aspects of the 
problem. It remains to be determined if teachers lack sensitivity to societal issues or do not regard it their role as science teachers to include values and ethical aspects. One might recognize the need of including these aspects in teacher education.

When they were asked as to what subjects of the CFD topic they would relate as a teacher, they mentioned 42 items which were clustered in three categories: scientific (20 items, 48\%); pedagogical (6 items, 14\%); societal issues (16 items, 38\%, provided by 9 teachers out of 30).

On question 5, when asked as what subjects on the topic of Fragile X Chromosome Syndrome (FXCS) they would like to integrate in their curriculum, teachers suggested 44 items: 41 of them on the scientific and only 3 related to societal aspects.

To question, 5a, what subjects on the topic of FXCS they would relate as a teacher, they mentioned 23 scientific items and only 5 societal issues.

Questions 4 and 5 yielded the same ratio of responses between the scientific and societal subjects related to CF and FXCS.

In question 6 teachers were asked that if they would be authorized to change or add to their genetics textbooks which included topics on human heredity and genetic engineering, what would they will suggest? Only 21 items were provided by the teachers and those responses were clustered in two categories: scientific and societal areas. Only 12 teachers suggested 16 (76\%) changes and additions to the scientific content related to genetic engineering, to update the content. As to the societal area, two teachers referred to the consequences on the use of genetic engineering, the need of articles on moral issues, euthanasia, genetic cloning and the application of genetic engineering to human problems, (5 items, 24\%).

In question 7, teachers were asked to suggest topics on the subject of embryo cloning that they would like to integrate into their teaching. The responses were clustered into two categories, and the results have shown that the teachers $(\mathrm{N}=17)$ suggested 27 items, equally divided: In the scientific area, 14 items $(52 \%)$ and on the societal issues 13 items (42\%).

The teachers were concerned with the scientific content and the ethical aspects of human cloning, including the Dolly experience and charlatans and dictators who could use biotechnology for their purposes. The issue of effectiveness vs. ethics was raised as well, and their reaction was strongly on the affective domain.

Finally, teachers' responses on question 1 were analyzed also by years of teaching experience, gender and faith.

There is a similar pattern of responses by the three groups of teachers relating to teaching experience. The greatest numbers of items are on Basic Genetics, followed by the other two groups, while the smallest number of items can be found in the societal issues. The only significant differences were found between the most experienced teachers and the other two groups in all the four categories. Teachers with more years of teaching experience tended to provide more items in the four categories. One might expect that novice teachers would provide more items on Basic Genetics, Molecular Biology and Genetic Engineering, due to the fact that they had recently concluded their university studies, but this was not the case. There is no indication that university studies had any particular impact on these issues; obviously, they preferred to stick to their textbooks. On the other hand, the teachers with 11 and more years of teaching experience felt more secure in surpassing their textbooks, and expressed more willingness to deal with new scientific subjects and with more issues that could lead to discussion on the affective domain. These results lead to assume that experienced teachers felt more secure in introducing issues and subjects in their teaching beyond those in their textbooks. Those teachers could be considered as being in their third stage of professional development according to Fuller and Parson (1969). They had probably overcome the survival period and the insecurity of not knowing enough science and pedagogy. They feel secure enough to address students' needs in terms of providing new and up to date learning material and relate to students' interests. Thus they are able to include affective values and ethical aspects, and use science in their daily life.

The other results indicated that the on four categories there are not did not any significant differences by gender and faith. The answers in the four categories showed no gender differences nor difference according to orthodox, traditional and secular teachers.

\section{Discussion}

The results indicate that among the teachers there is a medium to low level of awareness of societal issues, and 
the main emphasis is on the "pure" by scientific subjects taught for the matriculation exams. Most of the teachers do not include societal issues in their classes, as a planned part of their curriculum, but if students raise these issues, the teachers claimed to address them.

No differences in the teachers' opinions to societal aspects were found related to gender and religious faith. Teachers with more years of teaching experience tend to teach genetics with more of a STS approach than novice teachers. The novice teachers prefer to "stick" to basic and mandatory subjects.

The teachers explained not including debates on societal issues as an integral part of teaching genetics as follows: a) Their preoccupation with the matriculation examinations; b) Having to focus on subjects to be tested in these exams and having no time to prepare the students to them. All this drives the teachers to "stick to" the curriculum and teach it without any enrichment. Therefore, many teachers refrain teaching related to societal issues, which might have a moral or value orientation. One might assume that these attitudes are a result of the teachers' unwillingness to take a stand on issues that are not clear part of the curriculum and could contradict school policy and parents' values. Another explanation could be that if tools are given to the teachers in textbooks, preservice and in-service teacher education courses in which they should acquire skills and confidence needed to lead debates during science classes, then students could make decisions based on evidence and not on prejudice and misconceptions. Another explanation for not relating to societal issues can be according to Hughes (2000): "Teachers fear that extensive coverage of socio-science devaluates the curriculum, alienates traditional science students and jeopardize their own status as gatekeepers of scientific knowledge”. But Zohar and Nenet (2002) have shown that integrating explicit teaching of argumentation into the instruction of dilemmas in human genetics enhances the performance in biological knowledge and students are able to transfer reasoning skills to the context of dilemmas taken from everyday life. Therefore strategies of leading class discussions on societal issues bounded to subjects' matter that were depicted earlier, should be developed and investigated in the future.

School policy, teamwork and the teacher's perception of their role can also be reasons for not including societal issues in teaching genetics. What is the responsibility of the scientific community Gershon (1993) asked? Is and should science be neutral? Can knowledge be ethically dangerous? What is potentially more dangerous: knowledge or ignorance?

The answer to this question was actually answered during WWII, when, on the one hand the fraudulent use of knowledge led to genocide, and on the other hand ignorance was responsible for it as well. Citing Watson (2000: p. 3), who wrote "knowledge would liberate mankind from superstition", one may add that liberation from ignorance, prejudices and poverty not necessarily predict that circumstances cannot repeat themselves in the future. One may ask if it is the role of the universities to offer college courses on societal issues and bio-ethics (morals, ethics and values) not only in the philosophy departments but in that of sciences and technology too. The preand in-service courses for science teachers who teach genetics, evolution and related topics should include opportunities to discuss these issues in class (Muller-Hill, 1998, translator preface, Fraser, R.G. p. xii).

The roles of teachers at all levels should not be based on solely "dry" knowledge, but to address societal issues in open discussions, giving every one the opportunity to take a stand on science and technology developments. Only then we will be able to say that educating through the teaching science and technology can be relevant to students' needs as future citizens of our society. Knowledge cannot be neutral, it can only be human.

\section{Recommendations}

The findings of this study show the need for the implementation of discussions on societal issues related to science, technology and environment. In order to facilitate it, it is necessary to include these components in teachers' pre- and in-service education programs in science and technology university level. High school curricula should also include relevant open questions on these issues in the respective textbooks chapters. Students should be informed, and learn about the relationships between science, technology and society. The opportunities of finding jobs in a highly scientific-technological oriented society depend on whether or not these subjects are made available and relevant to the students' needs and interests.

We propose that students should realize the relevancy of the science curricula to their daily life and human needs. However, teachers and educators on all levels should provide an educational environment in which scientific knowledge will be acquired, based on solid moral, ethics and human values. Teaching in an inquiry mode integrated with the STS approach, rather the typical expository one, and new methods of teaching only does not assure humanistic and educational results. 
Another issue which should be considered, was the trend of separating the instruction of science and technology in the 60 's, in the then "new science curricula". This arose primarily as a result of political and social reasons, rather emanating from a profound philosophical debate. It is currently accepted that science and technology are interrelated, has a reciprocal influence on each other, and each contributing to the development of the other by a sequence of mutual contributions. Science and technology cannot be separated in the high school curricula and the teaching and cognitive skills involved should be firmly anchored on moral, ethical and human values as well.

It is our assumption that based on the crimes committed in World War II by German scientists, and now all over the world, and the possible future abuse of recent achievements in science and technology, decisions about their use should be based on ethical, moral, and human values. Therefore, instruction of science and technology should always be accompanied by opportunities in which students can relate and discuss their impact on human life and social justice.

Learning science and technology related to societal issues is one of the conditions that can free people from poverty, ignorance and prejudice. The results of scientific research should and can be objective, if its experiments are carried out according to the conventional rules accepted by the scientific community. However, the scientific results, findings and technological outcomes can be interpreted differently, based on the philosophical and moral values of those who make use of them, whether scientists or politicians.

We would like to end this part of our paper and to relate to the following:

1. It is astonishing to find in the German Chronicles of the Identification, Prescription, and Extermination of those who were "different" (Muller-Hill, 1998: p. 7-22), that the list of people who led to the atrocities of the World War II contains almost equal numbers of scientists in eugenics, evolution, medicine, euthanasia and anthropologists, and Nazi politicians. It is difficult to distinguish who influenced whom to be involved in these atrocities.

2. One comes to the same conclusion in reading the last pages, of the "Name Index", p. 233-246 (Muller-Hill, 1998). The number of German doctors who committed suicide at the end of the war, either to avoid trial or due to their feelings after their involvement in what they called "Aryan race theory" implementation, is comparable to the list of politicians and army officers who stood trial and were executed.

The two paragraphs mentioned above raise a more vital question regarding the science education in the 21st century. Our recommendation is that in each chapter in classic genetics, genetic engineering, evolution and natural selection, molecular biology, medicine and technology, relevant historical events should be introduced, as occurred due to the misleading interpretations of scientific theories, or intentional misuse which entailed criminal war activities. These topics of human history should be accompanied by class discussions, in which no one dictates his/her beliefs, but all are required to take a stand on moral, ethical and human values from a personal point of view. These issues become more acute to scientists and educators in recent times due to the demagogical manner in which poverty and religious faith are manipulated.

We must educate to understanding and respect of all believes. It is only possible to free people from ignorance, prejudice and poverty by teaching science and technology in a STS approach, combined with social and art sciences, to provide them with a solid humanistic basis for life. Although science and technology are included in our curriculum, the third component, the societal issues, require more attention.

Science education should go a step further, so that due to the recent advances in molecular biology, genetic engineering, the human genome project, evolution, eugenics and technologies, (with their potential applications for good and bad). All these disciplines, should include courses which address societal and bio-ethics issues, in order that future scientists understand their role and be aware of how dangerous is their impact on society. This is particularly true regarding the instruction of subjects like molecular biology, genetic engineering, medicine and technology related applications. Curricula developers, educators and scientist have to identify the appropriate subjects relevant to science, technology and societal issues, which can be integrated in order to provide learning material to be used in schools for achieving the goals suggested in this chapter.

This enterprise may "lessen the chance of a recurrence of a similar misuse and perversion of science and medicine in the future" (Muller-Hill, 1998, Translator preface, Fraser, R.G. p. xii). These recommendations can and should be applied in all the levels of formal education to all the science and technology subjects that could potentially affect human life.

\section{References}

Abrami, P. C., Poulsen, C., \& Chambers, B. (2004). Teacher Motivation to Implement an Educational Innovation: Factors 
Differentiating Users and Non-Users of Cooperative Learning. Educational Psychology, 24, 201-216. http://dx.doi.org/10.1080/0144341032000160146

Anderson, S. L. (2003). Teaching Today's Students How to Examine Ethical Issues and Be More Actively Involved in the Learning Process. Journal of Academic Publishers, 1, 189-198.

Aronson, E., Stephan, C., Sikes, J., Blaney, N., \& Snapp, M. (1978). The Jigsaw Classroom. Beverly Hills, CA: Sage Publication.

Bloom, B. S. (1956). Taxonomy of Educational Objectives: The Classification of Educational Goals. London: Longmans.

Bryant, J. A. (2002). Why I Believe That All Biology Degrees Study Should Include a Module in Bioethics. Times Higher Education Supplement, 14.

Bryant, J. A., \& Baggott la Velle, L. M. (2003). A Bioethics Course for Biology and Science Education Students. Journal of Biological Education, 37, 91-95. http://dx.doi.org/10.1080/00219266.2003.9655858

Bybee, R. W., Harms, N., Ward, B., \& Yager, R. (1980). Science Society and Science Education. Science Education, 64, 377-395. http://dx.doi.org/10.1002/sce.3730640312

Conner, N. L. (2000a). Inquiry, Discourse and Metacognition: Promoting Students' Learning in a Bioethical Context. The Annual Meeting of the National Association of Research in Science Teaching (NARST), New Orleans, LO.

Conner, N. L. (2000b). Societal Issues: Recommendations for Teaching in Science and Technology. Pacific Asian Education, 12, 19-30.

Conner, N. L. (2000c). The Significance of an Approach to the Teaching of Societal Issues Related to Biotechnology. The Annual Meeting of the American Educational Research Association (AERA), New Orleans, LO.

Dawson, V. (1998). Establishing Open and Critical Discourses in the Science Classroom: Reflecting on Initial Difficulties. Research in Science Education, 28, 317-336. http://dx.doi.org/10.1007/BF02461566

Dewey, J. (1927). The School and Society. Chicago, IL: The University of Chicago Press.

Dreyfus, A. (1995). Biological Knowledge as a Prerequisite for the Development of Values and Attitudes. Journal of Biological Education, 29, 215-219. http://dx.doi.org/10.1080/00219266.1995.9655448

Farmer, W. A., \& Farrell, M. A. (1980). Systematic Instruction in Science for the Middle and High School Years. Reading, MA: Addison Wesley.

Fuller, F. F., \& Parson, F. J. (1969). Concerns of Teachers: A Developmental Conceptualization. American Educational Research Journal, 6, 207-220. http://dx.doi.org/10.3102/00028312006002207

Gershon, H. (1993). Ethic in Life Sciences. In E. A. Halevi, \& D. Kohn (Eds.), Technology and Ethics, Proceedings of the International Symposium (pp. 37-42). Haifa: IIT, Technion.

Gilbert, R., \& Hoepper, B. (1996). The Place of Values. In R. Gilbert (Ed.), Studying Society and the Environment: A Handbook for Teachers (pp. 59-79). Melbourne: Mac Millan Publishing Company.

Gillies, R. M., \& Ashman, A. (2003). Co-Operative Learning: The Social and Intellectual Outcomes of Learning in Groups. London: Routledge Falmer.

Gottlieb, S. F. (1976). Teaching Ethical Issues in Biology. The American Biology Teacher, 38, 148-149. http://dx.doi.org/10.2307/4445515

Hertz-Lazarowitz, R. (1992). Understanding Students Interactive Behavior: Looking at Six Mirrors of the Classroom. In R. Hertz-Lazarowitz, \& N. Miller (Eds.), Interaction in Cooperative Groups (pp. 71-102). New-York: Cambridge University Press.

Hertz-Lazarowitz, R. (2005). Cooperative Learning in Israel. IASCE Newsletters. http://www.iasce.net

Hertz-Lazarowitz, R. (2008). Beyond the Classroom and into the Community: The Role of the Teacher in Expanding the Pedagogy of Cooperation. In: R. Gillis (Ed.), Thinking and Learning during Cooperative Learning (pp. 37-54). London: Rutledge Farmer.

Hughes, G. (2000). Marginalization of Socio-Scientific Material in Science-Technology-Society Science Curricula: Some Implications for Gender Inclusivity and Curricula Reform. Journal of Research in Science Teaching, 37, 426-440. http://dx.doi.org/10.1002/(SICI)1098-2736(200005)37:5<426::AID-TEA3>3.0.CO;2-U

Khalil, M. (2002). a) Microorganisms, a STS Learning Unit (in Arabic. p. 116, in Hebrew, p. 116). b) Teachers’ Handbook: Microorganisms, in Arabic, 76 p., in Hebrew, 76 p. Haifa: The Israel Science Teaching Center and the R \& D Institute, IIT, Technion.

Khalil, M., Lazarowitz, R., \& Hertz-Lazarowitz, R. (2009). A Conceptual Model, the Six Mirrors of the Classroom and Its' Application to Teaching and Learning about Microorganisms. Journal of Science Education and Technology, 18, 85-100. http://dx.doi.org/10.1007/s10956-008-9135-1

Khalil, M. (2007). Teaching the Microorganisms Learning Unit: Academic Achievements and Attitudes toward Environment 
and Peace of 9th Grade Students. Journal of Stellar Peacemaking, 2, 1-26.

Layton, D. (1993). Technology Challenge to Science Education. Milton Keynes: Open University Press.

Lazarowitz, R. (2000). Research in Science, Content Knowledge Structure, and Secondary School Curricula. Israel Journal of Plant Science, 48, 229-238.

Lazarowitz, R., \& Hertz-Lazarowitz, R. (1998). Cooperative Learning in Science Curriculum. In B. J. Fraser, \& K. G. Tobin (Eds.), International Handbook of Science Education (pp. 449-471). Dordrecht: Kluwer Academic Publishers.

Lazarowitz, R., \& Karsenty, G. (1990). Cooperative Leaning and Students’ Self-Esteem in Tenth Grade Biology Classroom. In S. Sharan (Ed.), Cooperative Learning: Theory and Research (pp. 123-149). New York: Praeger Publisher.

Lazarowitz, R., \& Bloch, I. (2006) Awareness of Societal Issues among High School Biology Teachers Teaching Genetics. Journal of Science Education and Technology, 14, 437-457.

Lazarowitz, R., \& Tamir, P. (1994). Research on Using Laboratory Instruction in Science. In D. Gabel (Ed.), Handbook of Research in Science Teaching and Learning (pp. 94-128). New York: The Macmillan Publishing Company.

Lipman, M. (1991). Thinking in Education. Cambridge: Cambridge University Press.

Muller-Hill, B. (1998). Murderous Science, Elimination by Scientific Selection of Jews, Gypsies and Others in Germany, 1933-1945. New York: Cold Spring Harbor Laboratory Press, Plainview.

Nachshon, M. (2000). Ionizing Radiation. The Biological Effects and Uses. Haifa, Israel: The Israel Science Teaching Center and the R\&D Institute, IIT, Technion, p. 153.

Ron, S., \& Lazarowitz, R. (1995). Learning Environment and Academic Achievement of High School Students Who Learned Evolution in a Cooperative Mode. The Annual Meeting of the National Association for Research in Science Teaching, NARST, San Francisco.

Rosenthal, D. B. (1984). Social Issues in High School Biology Textbooks: 1963-1983. Journal of Research in Science Teaching, 21, 819-831. http://dx.doi.org/10.1002/tea.3660210806

Sabar-Ben, J. (1997). The Qualitative Research in Teaching and Learning. Massada, Givataim, Israel, p. 32 \& 95. (In Hebrew)

Sharan, S., \& Hertz Lazarowitz, R. (1986). KooperativesLehren. In A. Weber (Ed.), Kooperatives Lehren und Lernen in die Schule (pp. 201-222). Agentur Dieck: Heinsberg, West Germany.

Watson, D. J. (2000). A Passion for DNA: Genes, Genomes and Society. Five Days in Berlin. New York: Cold Spring Harbor Laboratory Press, Plainview, 209-222.

Witenoff, S., \& Lazarowitz, R. (1993). Restructuring Laboratory Worksheet for Junior High School Students in the Heterogeneous Classroom. Research in Science and Technological Education, 11, 225-239. http://dx.doi.org/10.1080/0263514930110210

Zohar, A., \& Nenet, F. (2002) Fostering Students’ Knowledge and Argumentation Skills through Dilemmas in Human Genetics. Journal of Research in Science Teaching, 39, 35-62. http://dx.doi.org/10.1002/tea.10008 
Scientific Research Publishing (SCIRP) is one of the largest Open Access journal publishers. It is currently publishing more than 200 open access, online, peer-reviewed journals covering a wide range of academic disciplines. SCIRP serves the worldwide academic communities and contributes to the progress and application of science with its publication.

Other selected journals from SCIRP are listed as below. Submit your manuscript to us via either submit@scirp.org or Online Submission Portal.
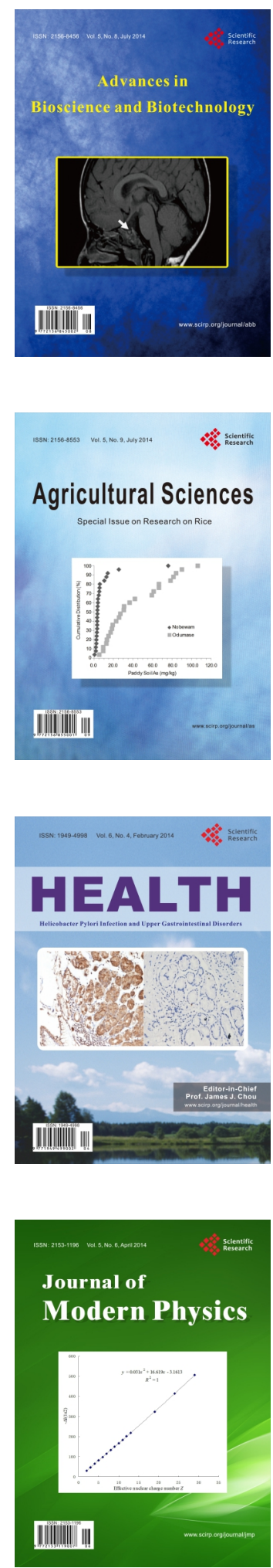
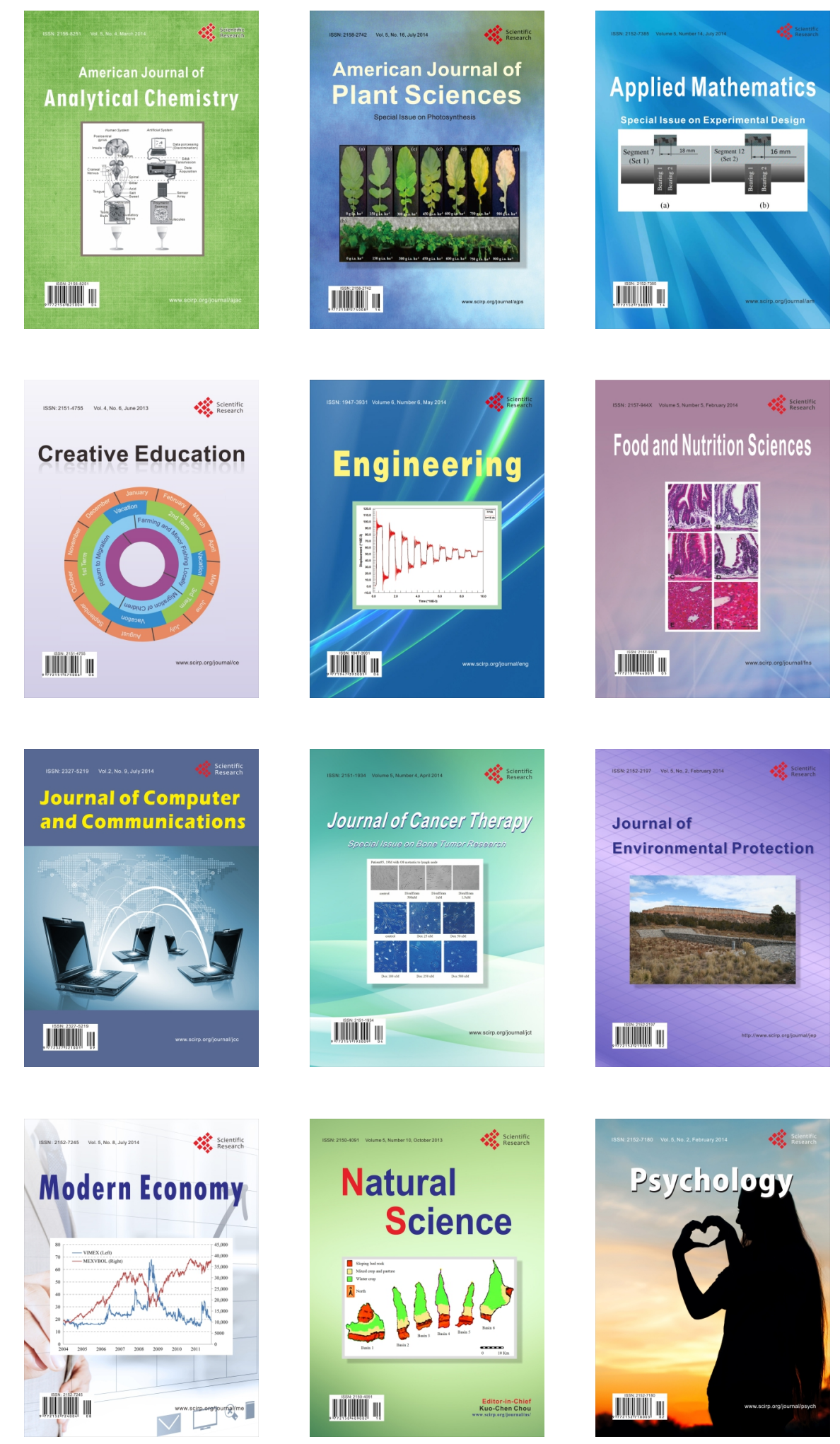